\title{
Housing Energy Equivalence: A Graphical Approach
}

\author{
Anna Pages-Ramon* (D), Judit Lopez-Besora (D), and Carlos Alonso-Montolio (D) \\ Architecture, Energy and Environment, School of Architecture, Universitat Politecnica de Catalunya, Barcelona, Spain
}

Received: 29 June 2021 / Received in final form: 20 September 2021 / Accepted: 20 September 2021

\begin{abstract}
All buildings, even the most passive, need active energy to provide habitability. Apart from heating and cooling needs, which have been broadly studied and regulated, a significant percentage of the energy consumed in housing is due to home appliances. Furthermore, this value is increasing as the design of environmental conditioning becomes more efficient. The objective of this paper is to visualize the impact of these consumptions by a graphical equivalence that uses drawing to represent the surface area of photovoltaic modules that correspond to the energy demand. With this aim, a straightforward method is proposed based on graphical means that fit well with the working practice of architects. The procedure starts by detailing the energy consumption of a home, focusing on the consumption values of all appliances and lighting. Next, each single value is converted into the surface area of photovoltaic modules required to produce this energy in one year. Finally, each appliance and its corresponding energy production area are represented graphically side by side, resulting in the housing energy equivalence. This method has been tested by a group of architecture master's students using their own homes as the case study. The results show that the energy equivalent surface area for lighting and appliances represents between $8 \%$ and $46 \%$ of the floor area of their homes. Altogether, this approach makes visible a pending question in sustainable building design - the consumption of electrical home appliances - and provides rough graphical data which is useful for pre-dimensioning in the architectural design process.
\end{abstract}

\section{Introduction}

The building sector is among those that contribute the most to energy consumption and carbon dioxide production worldwide. In 2018, $40 \%$ of the final energy consumption in Europe corresponded to this sector: $14 \%$ for services and $26 \%$ for households [1]. In the residential sector, statistics show that this energy is primarily used for space heating, space cooling, domestic hot water (DHW), cooking, lighting and electrical appliances [1-3].

For some years, the energy demand of the building sector has been constrained by a number of regulations across Europe [4-6]. These rules focus mainly on reducing the impact of heating, cooling and DHW, which represent $73 \%$ of the energy used in overall domestic consumption [2]. In non-residential buildings, lighting consumption is also regulated.

However, other uses such as electrical appliances are essential to make homes properly habitable. The energy demand of these appliances is regulated individually by

\footnotetext{
* e-mail: anna.pages@upc.edu
}

sectoral guidelines, which determine efficiency parameters. Nevertheless, building design requirements do not regulate the efficiency or number of appliances in households, and consequently this decision is beyond the designer's control. Today, household appliances use $19 \%$ of the energy consumed in the average home [2], however this percentage is expected to gradually rise if the energy demands for heating and cooling tend to decrease [7].

The energy demand for cooling and heating can be reduced by incorporating passive strategies into the building, however the demand from household appliances does not depend on architectural design. Nevertheless, buildings can influence the impact of the energy they consume by incorporating their own renewable energy production systems. One of these systems is photovoltaic energy (PV), which has been used increasingly in buildings and urban environments. For example, the number of self-consumption PV installations in Catalonia has increased from less than 1000 units in 2017 to almost 14,000 in June 2021, most of them vin the Barcelona metropolitan area [8], partially encouraged by governments and administrations. PV systems are easy to incorporate in buildings and urban elements [9], and enable the decentralization of energy production. 
Solar modules overlay the building envelope and make visible the impact of energy demand in buildings. Given that the energy produced by photovoltaic panels relates to their surface area, then the energy required to satisfy a particular demand may be expressed directly in square metres, in other words, in the same units of measurement as those employed in architectural design. As a result of this conversion, it is easy to determine the energy demand covered with a certain area of solar modules or, vice versa, the area of solar modules needed to cover a specific energy demand.

The objective of this paper is to make a graphical equivalence that uses drawing to represent the area of solar modules needed to cover the consumption of a single element, dwelling unit, or any particular type of energy demand, and thereby making it possible to understand its impact.

With this objective, the research uses a straightforward method that depicts the energy demand of buildings by establishing an equivalence between energy units and dimensional units. This type of conversion is similar to other ways of representing environmental impact, such as the ecological footprint [10], the ecological rucksack [11] or building energy labels $[4,12,13]$. All of them try to associate a 'graphical image' with the environmental impact of a certain activity.

This method fits well with the working practice of architects as it is based on graphical terms. In this field, it is essential to know the dimensions of all elements involved in the design process. These can be found in regulations, guides and handbooks [14-17] - one of the most useful and widespread documents is Neufert's handbook Bauentwurfslehre. Handbuch für den Baufachmann, Bauherren, Lehrenden und Lernenden [17] since it shows comprehensive architectural data with clear, dimensioned graphics. The latest editions of this manual have incorporated updated information such as the new building services sections, which include solar energy and renewable energy guidelines [18] - however, the dimensions associated with energy demand have not yet been included. The novelty of this paper lies in the fact that the energy needs in households are expressed graphically, in the same way that other elements are described in guides and handbooks.

This method was put into practice by a sample of Masters' students specializing in architecture, energy and environment at the Universitat Politècnica de Catalunya (UPC). The results of their work provide a case study to explain the graphical approach method, focused on the energy demand of electrical appliances and lighting. This method, like others carried out at postgraduate level [19-21] has helped students to expand their knowledge and consciousness of sustainability issues.

\section{Methodology}

The method used to produce this graphical equivalence is divided into four parts that can be more or less extensive depending on the data available.

\subsection{Data collection}

In the first stage, energy consumption data is required. Here, there are two possible options: using published data or collecting one's own data sets. In the first case, data can be obtained from various sources such as official reports, energy audits, specialized publications and others. The second option involves collecting data from existing buildings by monitoring energy consumption or checking electricity bills. The source that best fits the purpose of the application will be selected. It is recommendable to get detailed and real (not estimated) consumption data. The more thorough the analysis of the distribution of consumption, the more accurate the final result will be.

\subsection{Data analysis}

Once the detailed consumption of the unit of analysis has been obtained, the results may prove to be uneven. Therefore, at this stage, a numerical analysis will be needed to calculate the average value for each single unit consumed and the range of values. Apart from numerical analysis, knowledge of the conditions in which consumption data were obtained will help to discriminate those values that fall outside the range.

\subsection{Photovoltaic energy production data acquisition}

The production of energy with PV systems can be obtained either from calculations based on technical specifications or from existing solar power systems (production under real conditions). In both cases, the nature of the data has to be considered. On the one hand, production obtained from calculations represents an estimated value. Although this can be adjusted for foreseeable circumstances such as latitude or panel orientation, other unforeseeable circumstances like damage or lack of maintenance may affect the real measurement and distance it from the estimated value.

On the other hand, the values obtained in real conditions usually show lower production rates but are better adjusted to reality. Therefore, it is desirable to find the amount of energy produced per square metre of solar modules in a location and position as similar as possible to the case study. As with consumption data, the more closely data from PV production is adjusted to reality, the more reliable the conversion will be.

\subsection{Graphical equivalence outline}

The last step consists of directly converting energy consumption into PV surface modules by using the conversion unit previously obtained and applying it to equation (1). The graphical equivalence (EE) can be calculated by considering the energy consumption (EC) per appliance or habitation unit, or by using any other defined unit of analysis. The consumption values in square meters 
Table 1. Identification of the studied homes with their surface $\left(\mathrm{m}^{2}\right)$ and number of inhabitants.

\begin{tabular}{|c|c|c|c|c|c|c|c|c|c|c|c|c|c|}
\hline Id. Case & 1 & 2 & 3 & 4 & 5 & $6^{*}$ & 7 & 8 & 9 & 10 & 11 & 12 & 13 \\
\hline Surface $\left(\mathrm{m}^{2}\right)$ & 41 & 97 & 80 & 43 & 45 & 22 & 43 & 80 & 103 & 45 & 59 & 52 & 97 \\
\hline Number of inh. & 2 & 4 & 2 & 2 & 3 & 1 & 2 & 3 & 3 & 2 & 5 & 2 & 3 \\
\hline Id. Case & 14 & 15 & 16 & 17 & $18^{* *}$ & 19 & 20 & 21 & 22 & 23 & 24 & 25 & 26 \\
\hline Surface $\left(\mathrm{m}^{2}\right)$ & 85 & 65 & 53 & 75 & 73 & 85 & 93 & 66 & 40 & 80 & 110 & 35 & 33 \\
\hline Number of inh. & 2 & 2 & 3 & 3 & 5 & 4 & 4 & 4 & 2 & 4 & 3 & 2 & 1 \\
\hline
\end{tabular}

* Flat divided into $22 \mathrm{~m}^{2}$ lofts.

** Family home with one child.

Table 2. Total annual electricity consumption per household $(\mathrm{kWh} /$ year $)$, per square meter $\left(\mathrm{kWh} / \mathrm{m}^{2} \cdot\right.$ year $)$ and person $(\mathrm{kWh} /$ pers $\cdot$ year $)$.

\begin{tabular}{|c|c|c|c|c|c|c|c|c|c|c|c|c|c|}
\hline Id. Case & 1 & 2 & 3 & 4 & 5 & 6 & 7 & 8 & 9 & 10 & 11 & 12 & 13 \\
\hline kWh/year & 3234 & 1750 & 1375 & 1726 & 2710 & 968 & 731 & 4960 & 1347 & 2179 & 2994 & 1212 & 1878 \\
\hline $\mathrm{kWh} / \mathrm{m}^{2} \cdot$ year & 80 & 18 & 17 & 40 & 60 & 44 & 17 & 62 & 13 & 48 & 51 & 23 & 19 \\
\hline kWh/pers $\cdot$ year & 1617 & 437 & 688 & 863 & 903 & 968 & 365 & 1653 & 449 & 1090 & 599 & 606 & 626 \\
\hline Id. Case & 14 & 15 & 16 & 17 & 18 & 19 & 20 & 21 & 22 & 23 & 24 & 25 & 26 \\
\hline kWh/year & 945 & 754 & 991 & 1287 & 1300 & 3575 & 1377 & 4224 & 1866 & 3018 & 1264 & 2693 & 1908 \\
\hline $\mathrm{kWh} / \mathrm{y} \cdot \mathrm{m}^{2}$ & 11 & 12 & 19 & 17 & 18 & 42 & 15 & 64 & 47 & 38 & 11 & 77 & 58 \\
\hline kWh/pers $\cdot$ year & 473 & 377 & 330 & 429 & 260 & 894 & 344 & 1056 & 933 & 754 & 421 & 1347 & 1908 \\
\hline
\end{tabular}

are then represented on plan, where they can be compared with architectural dimensions.

$$
E E=\frac{E C}{E P}
$$

where $E E=$ Energy Equivalence $\left(\mathrm{m}^{2}\right) ; \quad E C=$ Energy Consumption $(\mathrm{kWh} /$ year $) ; \quad E P=$ Energy Production $\left(\mathrm{kWh} / \mathrm{m}^{2} \cdot\right.$ year $)$.

\section{Case study}

The case study is composed of a sample of 26 dwellings of masters' students between 25 and 30 years old from different countries. All of them were architects studying the one-year specialization Architecture, Energy and Environment of the Master's Degree in Advanced Studies in Architecture-Barcelona (MBArch-UPC) between 2018 and 2021. They lived away from their family residences in shared or individual apartments, which implies a different user profile compared with a family home. In this situation, life tends to be more individual which may influence the distribution and weighting of detailed energy consumption.

Each student obtained the electrical appliances and lighting consumption data from their homes, analysed it, and depicted the corresponding graphical equivalence. The list of homes is shown in Table 1 with the surface and the number of inhabitants of the apartments.

\section{Methodology application and results}

The following steps show the results of this method as applied to the case study. Each step is also explained with the particular circumstances in which the students developed it.

\subsection{Data collection}

The energy consumption data used to apply this method was gathered by the students. They obtained this information from their homes during a period of three weeks, focusing on lighting and home appliances. The source of data was diverse, depending on the element or system considered:

- Measured data with power meters during a specific time period; used in single home appliances;

- Calculation based on estimated usage hours and power data from appliances' technical datasheets, when it was not possible to use power meters;

- Readings on home electricity meters; used to obtain the total amount of energy consumption in a fixed period of time;

- Electricity bills; which show the energy consumed during the billing period (usually, one month).

Given that each student had different housing conditions, the available means of obtaining data was not always the desired option. The data collection is therefore adapted for this and is reflected in the results. Therefore the more appliances that have been individually measured with power meters, the more accurate and reliable the results will be.

The results of the total electrical consumption, listed in Table 2, show a certain dispersion caused by the variety of situations considered (the values range evenly from 731 to $4960 \mathrm{kWh} /$ year). It is worth mentioning that the uses and 


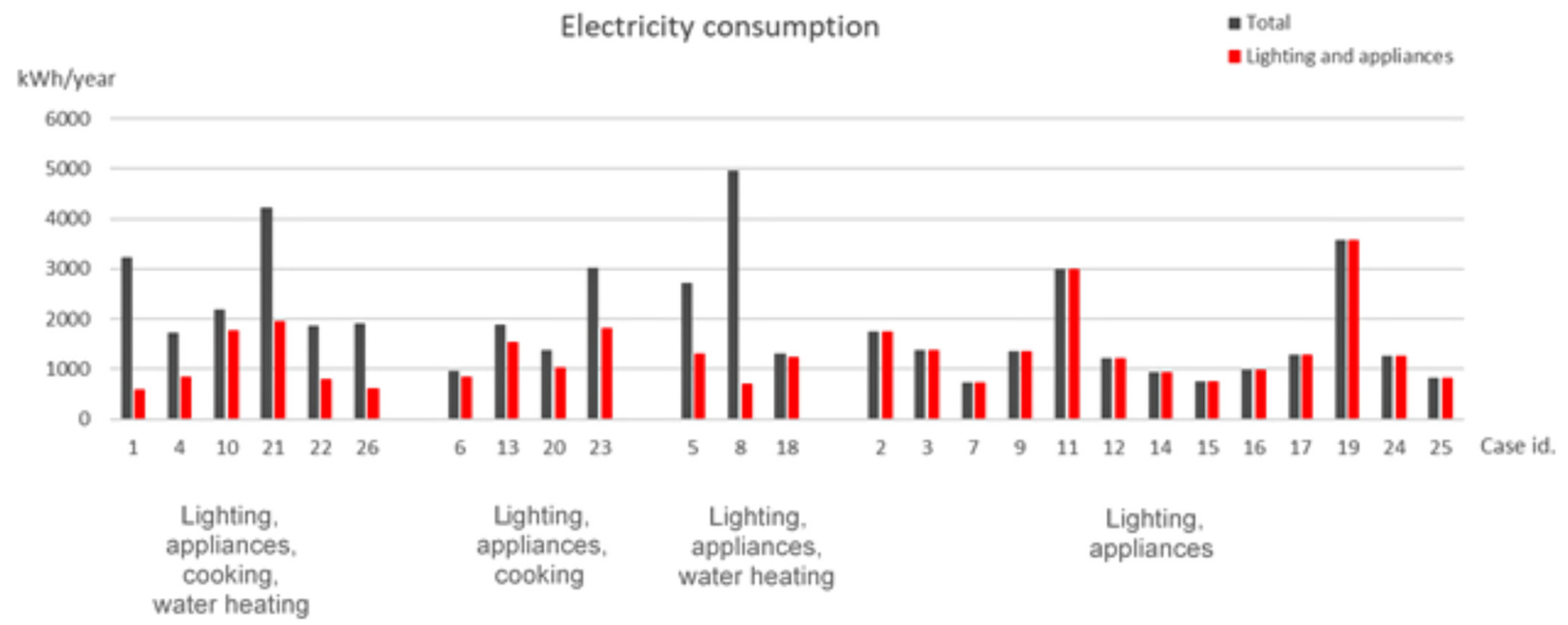

Fig. 1. Total annual electricity consumption per household (kWh/year), pooled by covered uses.

elements which used electricity were different in each case. As shown in Figure 1, these were categorised into four groups:

- Lighting, appliances, cooking, water heating;

- Lighting, appliances, cooking;

- Lighting, appliances, water heating;

- Lighting, appliances.

In Spain, according to the Institute for the Diversification and Saving of Energy (IDAE) [22], the annual energy consumption per dwelling in multifamily housing is $2065 \mathrm{kWh} /$ year for appliances (including standby) and $397 \mathrm{kWh} /$ year for lighting, which gives a total of $2462 \mathrm{kWh} /$ year. This value corresponds to the uses depicted with red bars in Figure 1, which ranges from 598 to $3575 \mathrm{kWh} /$ year, with an average of $1314 \mathrm{kWh} /$ year. The variation in values can be the result of: the floor area of the apartment, the number of people, the lifestyle and income of inhabitants, the efficiency of appliances, etc. [23].

Apart from the total value, each student drew up a table of consumption for home appliances and lighting broken down which is depicted later on.

\subsection{Data analysis}

The analysis focuses on obtaining the average consumption which makes up for the higher and lower values of the sample, covering all situations in the range. The average is calculated for each category in order to obtain a representative energy consumption per element.

The data obtained, which reveals some dispersion, was put together in a graph (Fig. 2). It shows a maximum of 26 values for each category (depending on the number of students who listed it), along with the calculated average value. The consumptions analysed are: refrigerator, washing machine, television, computer/laptop, dishwasher, oven, router, and mobile phone. Another category corresponding to other electrical appliances was also considered. This is a very large group containing numerous electrical and electronic devices of different natures, most of them corresponding to kitchen uses (for example, toaster, coffee maker, mixer or kettle), bathroom uses (for example, shaver, hair dryer or electric toothbrush) and other uses. The list also contains energy consumption for lighting. The values offered by the IDAE [22] are also shown as a reference. The categories are put in order from maximum to minimum according to the consumption value offered by IDAE.

To summarize the data, Table 3 shows the average value along with the median, the maximum and minimum values obtained for each category. The categories with a zero value were not considered in the numerical analysis. From the results obtained, it was decided to use the average value to make the graphical equivalence, as it better covers all the situations within the range.

This step was not applied in the same way in the exercise developed in class. In this case, the sample of values comprised other students of the same year, so the analysis consisted of the validation of their own results using those from their fellow students to verify reliability and to identify possible misleading values.

\subsection{Photovoltaic energy production data acquisition}

The data on photovoltaic energy production applied to this methodology was acquired from installations located in the city of Barcelona. It was provided by Grup TERSA (Tractament i Selecció de Residus, S.A.), a public company specialized in the management of environmental services, including the generation and commercialization of renewable energy. 


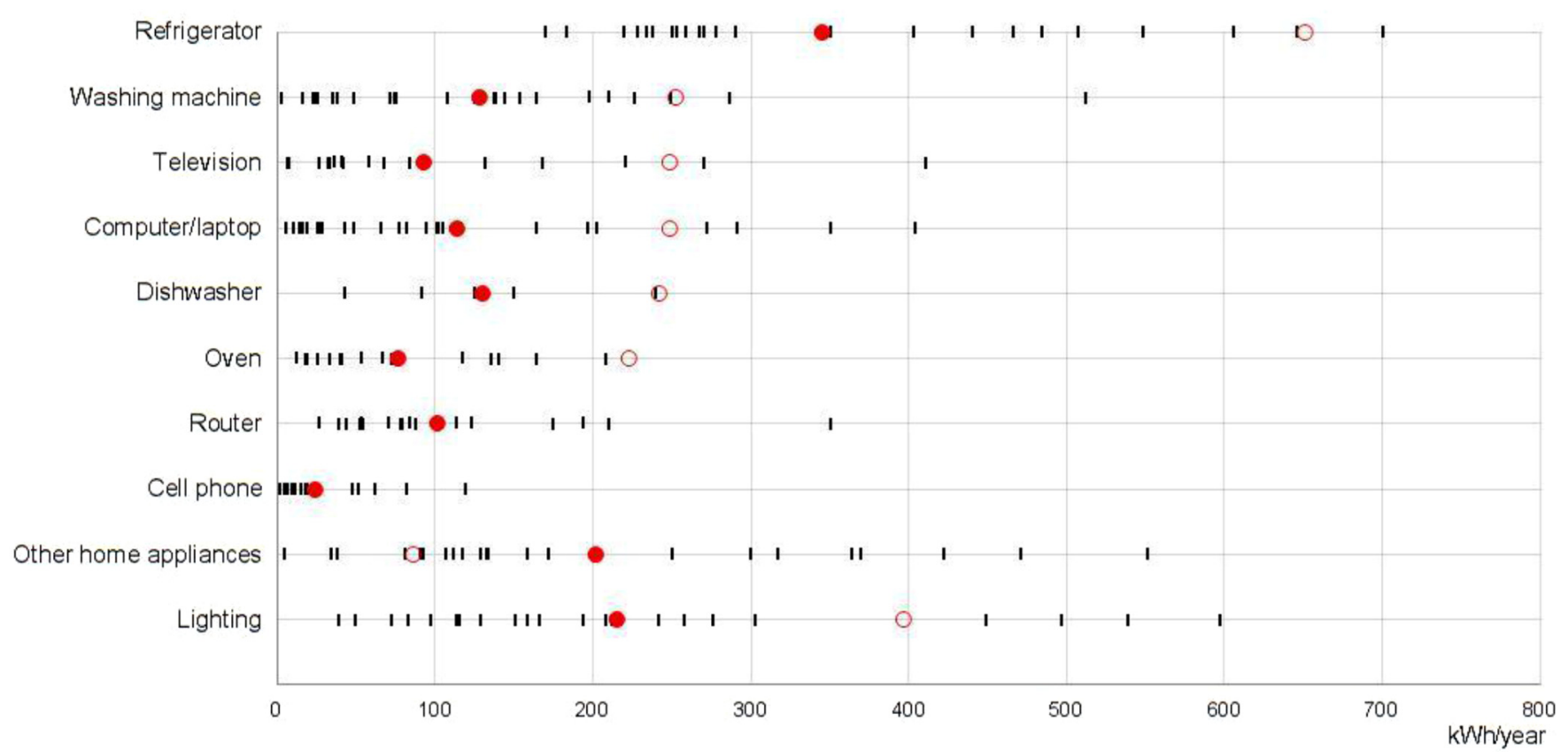

Fig. 2. Annual electricity consumption per element/category (kWh/year). Case study data collected (black); case study average (red dot); IDAE reference values [22] (red circumference).

Table 3. Average, median, maximum and minimum annual consumption values listed per category (kWh/year).

\begin{tabular}{lllll}
\hline & $\begin{array}{l}\text { Average } \\
(\mathrm{kWh} / \text { year })\end{array}$ & $\begin{array}{l}\text { Median } \\
(\mathrm{kWh} / \text { year })\end{array}$ & $\begin{array}{l}\text { Minimum } \\
(\mathrm{kWh} / \text { year })\end{array}$ & $\begin{array}{l}\text { Maximum } \\
(\mathrm{kWh} / \text { year })\end{array}$ \\
\hline Refrigerator & 346 & 269 & 169 & 700 \\
Washing machine & 129 & 116 & 2 & 512 \\
Television & 93 & 41 & 6 & 411 \\
Computer/laptop & 114 & 88 & 5 & 403 \\
Dishwasher & 130 & 125 & 43 & 240 \\
Oven & 76 & 53 & 11 & 208 \\
Router & 101 & 81 & 26 & 350 \\
Cell phone & 24 & 11 & 2 & 119 \\
Other home appliances & 237 & 146 & 4 & 551 \\
Lighting & 273 & 180 & 39 & 597 \\
\hline
\end{tabular}

The production data corresponds to one-year generation values from $44 \mathrm{PV}$ facilities located in Barcelona. In 2019, these systems produced $1451 \mathrm{MWh}$. According to the municipality, this energy is supplied by $9898 \mathrm{~m}^{2}$ of PV panels [24].

In order to obtain a representative production value per surface unit $\left(\mathrm{kWh} / \mathrm{m}^{2}\right)$, the relation was calculated in each photovoltaic facility. After discarding two incoherent values, the results show an even distribution of unitary energy production per system (Fig. 3). The final weighted average, considering the total PV area, is $144 \mathrm{kWh} / \mathrm{m}^{2}$. This value was chosen to depict the graphical equivalence in the following step.
The students applied the methodology before having TERSA data. Therefore, they developed this exercise using the PV production value from a single installation in Barcelona that has been registering data for the last 20 years. The production value used was $110 \mathrm{kWh} / \mathrm{m}^{2}$.

\subsection{Graphical equivalence outline}

The last step and the objective of this method is represented by the graphical equivalence of the electrical energy consumption. It consists of depicting the PV surface area needed to meet the energy consumption of the elements or uses considered per home unit. The conversion 


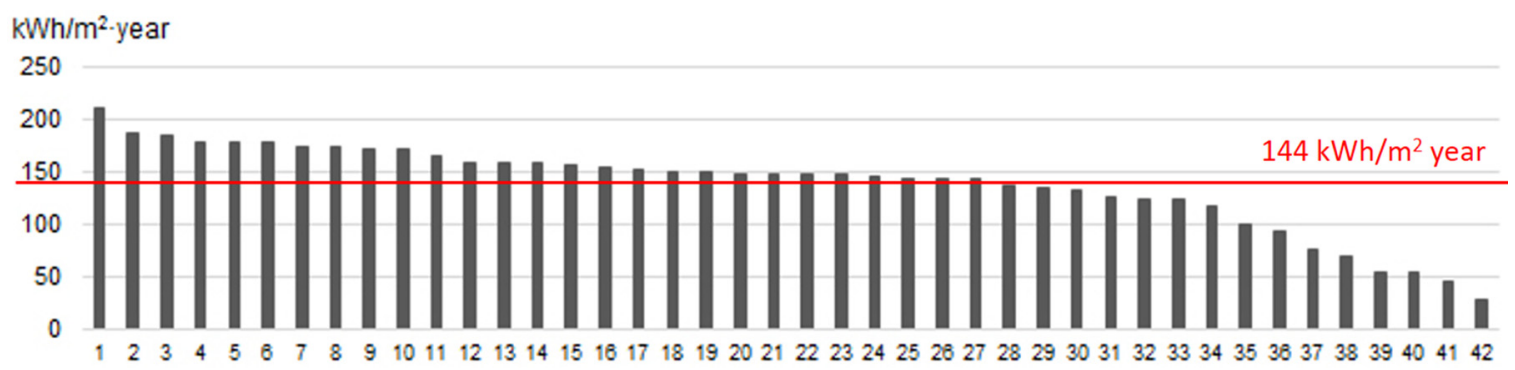

Fig. 3. PV production value per surface unit $\left(\mathrm{kWh} / \mathrm{m}^{2}\right)$ in 42 photovoltaic facilities located in Barcelona. Own elaboration based on data from TERSA and [24].

in square meters has been made individually, according to equation (1), for the 8 main home appliances and 2 groups: other appliances and lighting. Their equivalent PV surface production is depicted side by side with the element considered, both at the same scale (Fig. 4). The values employed to determine the graphical equivalence are the annual average consumption calculated in Section 3.2 and the annual PV production obtained in Section 3.3 $\left(144 \mathrm{kWh} / \mathrm{m}^{2}\right)$.

In the case developed by the Masters' students, they each represented their own detailed consumptions appliance by appliance. They also depicted the PV area required to meet the total electrical energy consumption of the home alongside the floor plan. In all drawings, the same scale was used in order to be comparable with architectural dimensions. An example is shown in Figure 5.

From the results, the proportion of the dwelling's floor area needed to cover the energy consumption of electrical appliances and lighting of students' homes ranges from 8 to $46 \%$ ( $20 \%$ on average). It is worth highlighting that the indicated values are the minimum physical surface area needed to obtain the required average annual energy. Peak power has not been considered, as well as other processes like transformation-retransformation, and controls.

\section{Discussion}

The graphical equivalence is the final step of this method, providing the visible representation of energy units in the context of architecture. The interpretation of the results is determined by the source of the data, both in the case of consumption data and PV production.

Regarding the consumption data, it is worth noting that although the selected sample shows a certain uniformity in the type of dwelling (all of them are student flats), this uniformity is not reflected in the results. The dispersion on the electrical appliances and lighting consumption, from 598 to $3575 \mathrm{kWh} /$ year, can be explained by the wide range of efficiency of the appliances and the different number of people and their habits.
Compared with other consumption data reports in Spain $[3,22]$, the values of this study have proven to be much lower. This is also the case with all the elements studied, with the exception of the group of other electrical appliances, which has much higher consumption than national reports. It has not been possible to precisely determine the causes of this discrepancy. Possible explanations could be the time gap between the data compared and the fact that the sample in the case study is composed only of students.

Beyond the differences, it is worth emphasizing the importance of the values collected, which were gathered by the students themselves and constitute consumption values for their well-known domestic environment. Therefore, it constitutes a valuable and contextualized reference about household energy values. In addition, they can compare their own values with any other reference, from either their classmates or reports.

In terms of PV production, it is valuable to have data from real systems in a similar situation instead of purely theoretical estimates. The value used is local and cannot be extrapolated. Also, it should be updated from time to time to include future improvements in PV efficiency. The numerical equivalence used here comes from a wide range of real measurements and has been updated with respect to the initial values used by the students.

Finally, the resulting graphical representation offers two approaches. On the one hand, it shows a summary with the dimensional needs to supply electricity detailed by appliances. Thus, the area depicted for the appliances analysed ranges from $0.17 \mathrm{~m}^{2}$ to $2.4 \mathrm{~m}^{2}$. On the other hand, it allows the graphical comparison between the floor area of a dwelling and the area needed for the energy production of its electrical appliances. On average, the PV surface depicted by the students is equivalent to $20 \%$ of the floor area of their home (ranging from 8 to $46 \%$ ). Based on this, if the roof alone was used for energy production, the building could meet the electricity demand of at most 5 floors. However, it must be taken into account that these consumptions represent only a third of total domestic energy consumption. 


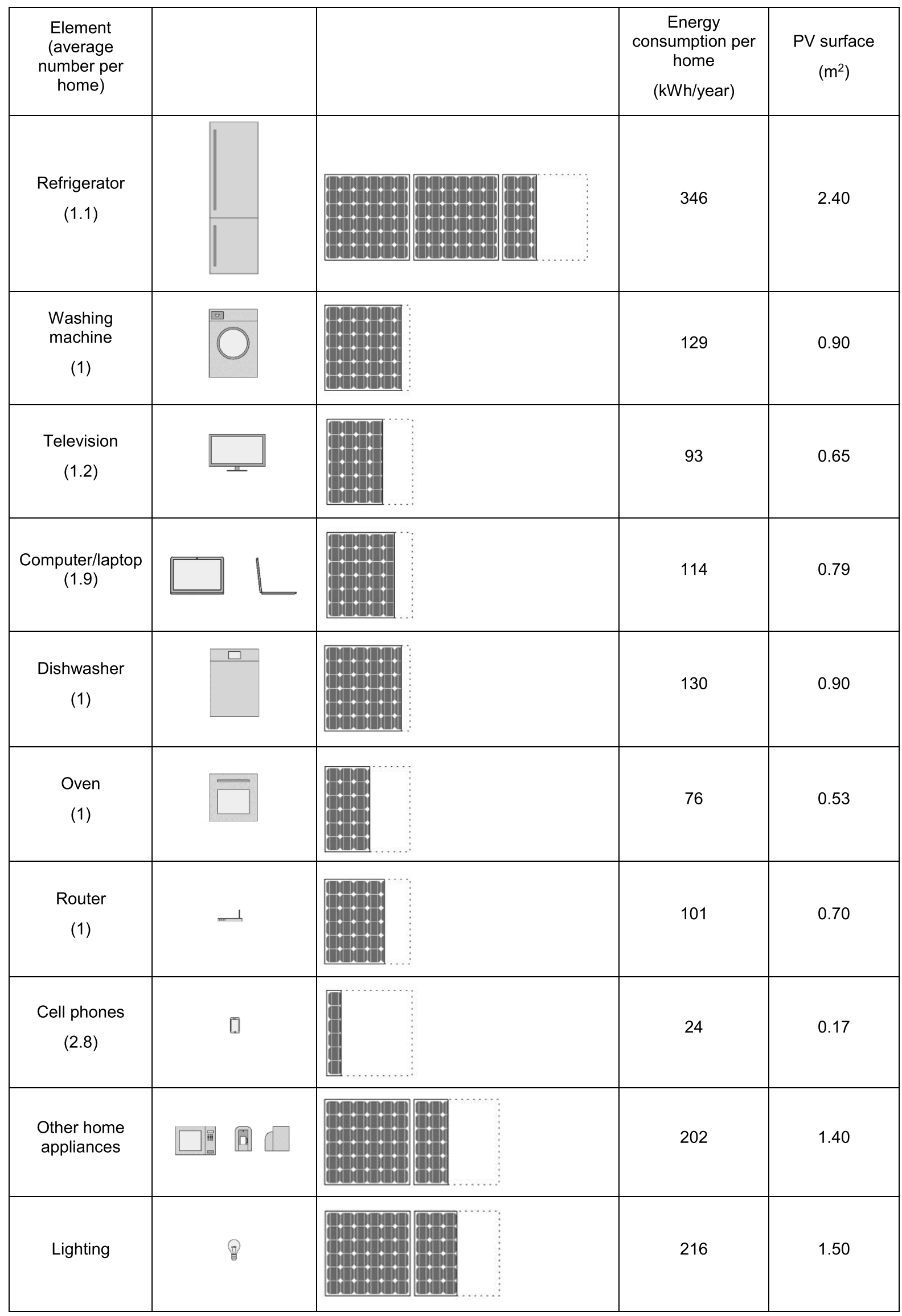

Fig. 4. Graphical energy equivalence of lighting and the main home appliances in the case study. 

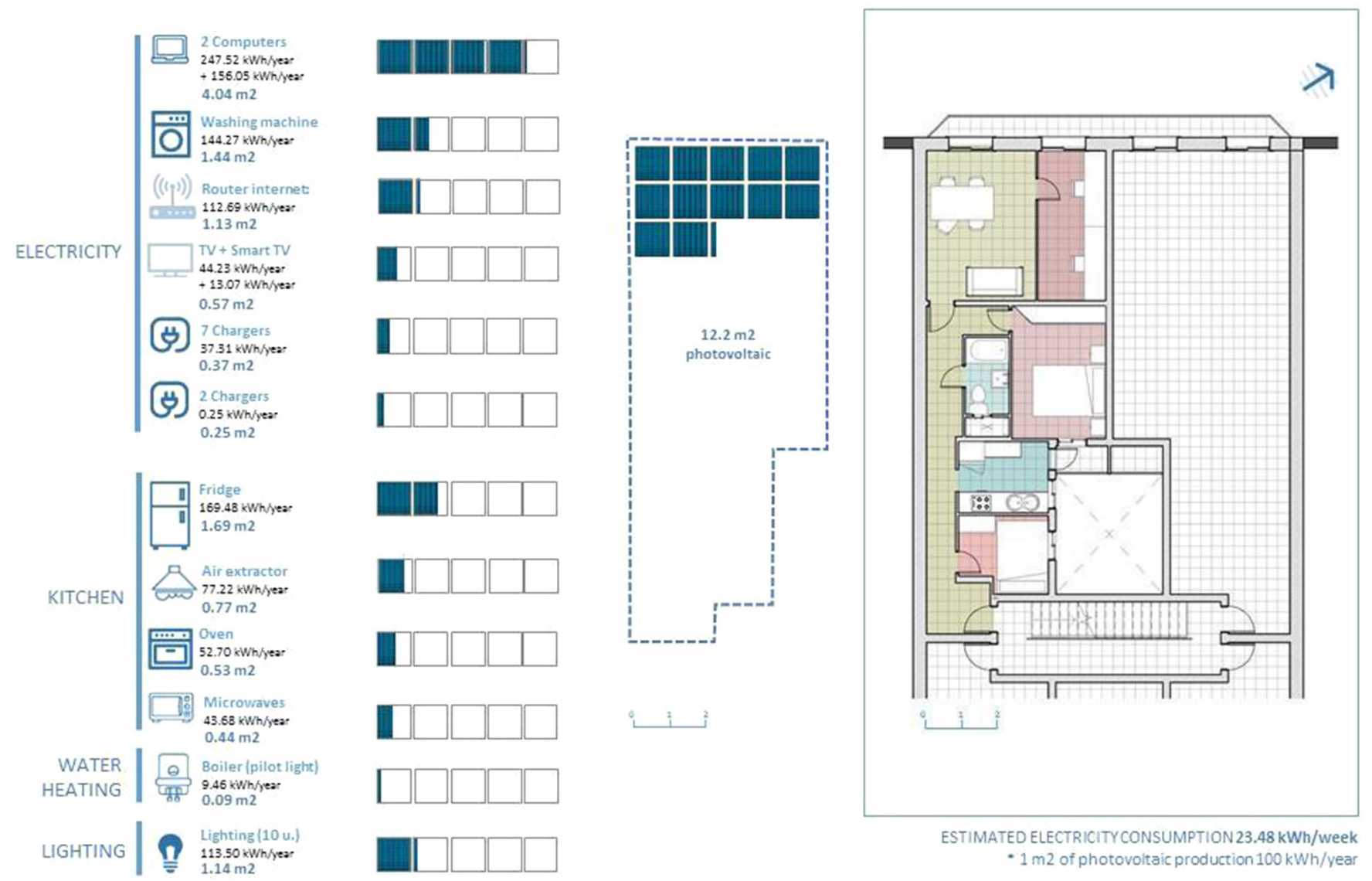

Fig. 5. Example of housing energy equivalence at dwelling scale. Source: [25].

\section{Conclusions}

This method has described a procedure to provide a graphical representation of energy consumption (or demand) in homes, focusing on electrical appliances and lighting. Its relevance lies in the fact that it makes it possible to visualize energy in a tangible way. Usually, energy is expressed with numerical data, making it difficult to perceive its impact. Drawing a correlation between energy and dimensional units helps to visualize this impact through common architectural units. It is especially valuable in the case of electrical appliances, which remain beyond the scope of architectural design, but play an important part in the total energy consumption of homes.

The values obtained for electrical home appliances and lighting show that, even though the case study was composed of similar types of dwellings, user habits influence energy consumption, and when analysed may give wide ranges of values. The consumption values for lighting and other home appliances in the case study ranged from 598 to $3575 \mathrm{kWh} /$ year, with an average of $1314 \mathrm{kWh} /$ year, which is $47 \%$ lower than the values of the main Spanish report for the same uses.

As a result of the collection and analysis of consumption data using this method, two aspects have arisen. First of all, the sample selected for the case study has great influence on the results, since it affects the patterns of consumption. Secondly, the specific application of the methodology in the first stage, that of data collection, also influences the result, as it can be more precise and realistic or estimated depending on the availability of bills, energy meters or other sources. Hence, it is important to bear these aspects in mind in order to interpret the results correctly.

Regarding the PV production obtained, it is of particular note that the paper offers a reliable reference value $\left(144 \mathrm{kWh} / \mathrm{m}^{2}\right.$. year) that can be extrapolated to other studies in the Barcelona area.

The results presented are useful for determining the PV surface area needed to cover electrical demand in homes. It can be applied to the usual appliances one by one, or to the unit of habitation considering the typical equipment needed. In fact, the main contribution of this paper is the depiction of energy consumption with scale drawings, similar to one of the most widely used manuals, Neufert's handbook, but in the field of energy.

The exercise developed in class has broadened students' knowledge of energy use, demand, and consumption while visualizing the spatial requirements for energy production. Despite the fact that rough data is used, the drawings represent the order of magnitude of these consumptions. 
The results of the work presented show that one fifth of the floor area is needed to cover the energy consumption of electrical appliances and lighting in homes.

Acknowledgements. This research has been supported by the Spanish Ministry of Economy under project code BIA2016-7765$\mathrm{R}$. We acknowledge the work of the students of the Architecture, Energy and Environment specialization line within the Master's Degree in Advanced Studies in Architecture-Barcelona (MBArch-UPC), years 2018-19, 2019-20, 2020-21 and also TERSA Group.

\section{References}

1. Eurostat, Energy Statistics [on line]. European Commission. [Accessed: 21 December 2020]. Available at: https://ec. europa.eu/eurostat $/ \operatorname{tgm} /$ table.do?tab=table\&init=1\&lan guage $=$ en\&pcode $=$ ten $00124 \&$ plugin $=1$

2. IEA, Shares of residential energy consumption by end use in selected IEA countries, 2018 [online] (IEA, Paris, 2018). Available at: https://www.iea.org/data-and-statistics/ charts/shares-of-residential-energy-consumption-by-enduse-in-selected-iea-countries-2018 (Accessed: 28 December 2020)

3. Institute for the Diversification and Saving of Energy IDAE. Proyecto SECH-SPAHOUSEC. Análisis del consumo energético del sector residencial en España [on line] (Ministerio de Industria, Turismo y Comercio, Madrid, 2011). Available at: https://www.idae.es/uploads/documen tos/documentos_Informe_SPAHOUSE C ACC f68291a3.pdf (Accessed: 28 December 2020)

4. European Union, Directive 2010/31/EU of the European Parliament and at the Council of 19 May 2010 on the energy performance of buildings, Off. J. Eur. Union 18, 13 (2010)

5. European Union, Directive 2012/27/EU of the European Parliament and of the Council of 25 October 2012 on energy efficiency, amending Directives 2009/125/EC and 2010/30/ EU and repealing Directives 2004/8/EC and 2006/32/EC, Off. J. Eur. Union 315, 1 (2012)

6. European Union, Directive 2018/844 of the European Parliament and of the Council of 30 May 2018 amending Directive $2010 / 31 / \mathrm{EU}$ on the energy performance of buildings and Directive 2012/27/EU on energy efficiency, Off. J. Eur. Union 156, 75 (2018)

7. Ministerio de Transportes, Movilidad y Agenda Urbana. ERESEE 2020. Actualización 2020 de la Estrategia a Largo Plazo para la Rehabilitación Energética en el Sector de la Edificación en España. [on line]. Gobierno de España, 2020. [Accessed: 15 September 2021]. Available at: https://www. mitma.gob.es/recursos_mfom/paginabasica/recursos/es ltrs 2020.pdf

8. Institut Català de l'Energia, Autoconsum Fotovoltaic a Catalunya. Generalitat de Catalunya, 2021. Available at: http://icaen.gencat.cat/web/.content/10_ICAEN/17_pub licacions informes/08 guies informes estudis/informes i_estudis/arxius/20210826_Ā AutoconsumFVjuny21Acc.pdf (Accessed: 20 September 2021)

9. H. Coch, C. Pardal, A. Pages-Ramon, A. Isalgue, I. Crespo, Better than optimum: integrated: the integration of renewable energy in architecture as an optimization factor, in Renewable Energy in the Service of Mankind Vol II: Selected Topics from the World Renewable Energy Congress WREC 2014 (Springer, 2016), ISBN. 978-3-319-18215-5

10. M. Wackernagel, W. Rees, Our Ecological Footprint. Reducing Human Impact on the Earth, New Society Publishers, Gabriola Island, 1996

11. F. Cahyandito, The MIPS Concept: A Measure for an Ecological Economy. Conference, Exhibition on Industry and Technology, International Seminar [on line] Hamburg, Germany. 2 October 2002 [Accessed: 28 March 2021] Available at: https://papers.ssrn.com/sol3/papers.cfm? abstract id $=1670709$

12. Spain, Real Decreto $235 / 2013$, de 5 de abril, por el que se aprueba el procedimiento básico para la certificación de la eficiencia energética de los edificios, Boletín Oficial del Estado. 13 April 2013, no. 89. p. 27548

13. Ministerio para la transición ecológica y el reto demográfico. Energía y desarrollo sostenible. [on line]. Gobierno de España [Accessed: 28 March 2021]. Available at: https:/ / energia.gob. es/desarrollo/EficienciaEnergetica/CertificacionEnergetica/ DocumentosReconocidos/normativamodelosutilizacion/ETI QUETA\%20EDIFICIO\%20TERMINADO.pdf

14. Código técnico de la edificación: CTE (Thomson Paraninfo, Madrid, 2006), ISBN 8428329400

15. Fondation Le Corbusier, The Modulor and Modulor 2, edited by Birkhauser (2015). ISBN 9783764361884

16. E. Steegman, J. Acebillo, Las Medidas en arquitectura, edited by Gustavo Gili (Barcelona, 2008), ISBN 9788425222375

17. E. Neufert, Bauentwurfslehre. Handbuch für den Baufachmann, Bauherren, Lehrenden und Lernenden, edited by Bauwelt-Verlag (1st edition) (1936)

18. E. Neufert, Arte de proyectar en arquitectura: generalidades, normas, directrices sobre disposición, construcción, diseño, superficies requeridas, relaciones espaciales, medidas para edificios, espacios, instalaciones, aparatos con el ser humano como medida y fin, edited by Gustavo Gili (Barcelona, 2013), ISBN 9788425224744

19. H. Bryan, M. Grimm, Carbon footprinting: a classroom exercise, in Proceedings of the 26th International Conference on Passive and Low Energy Architecture PLEA (2009)

20. I.R. Cantalapiedra, M. Bosch, F. Lopez, Involvement of final architecture diploma projects in the analysis of the UPC buildings energy performance as a way of teaching practical sustainability, J. Clean. Prod. 14, 958-962 (2006)

21. M. Dabaieh, D. El Mahdy, D. Maguid, Living labs as a pedagogical teaching tool for green building design and construction in hot arid regions, Int. J. Architect. Res. 12, 338-355 (2018)

22. Institute for the Diversification and Saving of Energy (IDAE). Consumos del Sector Residencial en España. 
Resumen de Información [on line] (Ministerio de Industria, Turismo y Comercio, Madrid, 2021). Available at: https:// www.idae.es/uploads/documentos/documentos_Documen tacion_Basica_Residencial_Unido_c93da537.pdf (Accessed: 28 March 2021)

23. M. Anglada Barber, La Repercusión del Usuario en el Consumo Energético en Viviendas de Barcelona. Master Thesis, Universitat Politècnica de Catalunya, 2015
24. Ajuntament de Barcelona, AjBCN-Xarxa fotovoltaica amb connexió a la xarxa elèctrica [online]. Available at: https://www.google.com/maps/d/viewer? $\operatorname{mid}=1 \mathrm{IKOXPN}$ GoI_us1Juke5PoLZHu3ms\&ll $=41.408571111427946 \%$ 2C2.144829706445206\&z=12 (Accessed: 10 March 2021)

25. P. Carrillo Arancibia, Estudio Consumo Energético. Architecture, Energy and Environment, Master's Degree in Advanced Studies in Architecture-Barcelona (UPC), 2019 (unpublished)

Cite this article as: Anna Pages-Ramon, Judit Lopez-Besora, Carlos Alonso-Montolio, Housing Energy Equivalence: A Graphical Approach, Renew. Energy Environ. Sustain. 6, 36 (2021) 